\title{
Xanthogranulomatous salpingitis - pathological aspect of chronic pelvic inflammatory disease in a patient with sigmoid diverticulitis
}

\author{
Sunil Kumar Juneja ${ }^{1}$, Satpal Singh Virk², Anjali Sharma ${ }^{1 *}$, Neena $\operatorname{Sood}^{3}$, Ajit Sood ${ }^{4}$
}

\begin{abstract}
${ }^{1}$ Department of Obstetrics and Gynecology, ${ }^{2}$ Department of Gastrosurgery, ${ }^{3}$ Department of Pathology, ${ }^{4}$ Department of Gastroenteology, Dayanand Medical College and Hospital, Ludhiana, Punjab, India
\end{abstract}

Received: 26 June 2018

Accepted: 26 July 2018

\section{*Correspondence: \\ Dr. Anjali Sharma, \\ E-mail:dranjali17@gmail.com}

Copyright: (c) the author(s), publisher and licensee Medip Academy. This is an open-access article distributed under the terms of the Creative Commons Attribution Non-Commercial License, which permits unrestricted non-commercial use, distribution, and reproduction in any medium, provided the original work is properly cited.

\begin{abstract}
A case of Xanthogranulomatous salpingitis in 55yrs old women with sigmoid diverticulitis is presented. Xanthogranulomatous inflammation is an uncommon form of chronic inflammation which affects various organs and is destructive in nature. This inflammatory process is characterized by massive infiltration of the tissues by lipid laden histiocytes admixed with lymphocytes, plasma cells and polymorphonuclear leucocytes. Pelvic inflammatory disease is the main etiology. This could have possibly resulted in xanthomatous process in our case leading to xanthogranulomatous salpingitis.
\end{abstract}

Keywords: PID, Salpingitis, Xanthogranulomatous

\section{INTRODUCTION}

Xanthogranuomatous inflammation is a type of chronic inflammation which affects various organs and is destructive in nature. Around 13 related cases of xanthogranulomatous inflammation involving fallopian tube and ovary have been described in English Literature. ${ }^{1-10}$ The youngest documented case is of 18 years old female by Shilpa et al. ${ }^{11}$

This inflammatory process is characterized by massive infiltration of the tissues by lipid laden histiocytes admixed with lymphocytes, plasma cells and polymorphonuclear leucocytes. ${ }^{12}$

There are various etiologies postulated which are contributory factors in the pathogenesis of Xanthogranulomatous inflammation. Pelvic inflammatory disease is the main etiology. Other factors include necrosis, haemorrhage and obstruction. ${ }^{13-15}$ Authors report a case of 55 years old postmenopausal woman with sigmoid diverticulitis diagnosed with Xanthogranulomatous salpingitis.

\section{CASE REPORT}

A 55yrs old postmenopausal woman presented with lower abdominal pain more in left groin region with per vaginal white discharge and anorexia since 3 months.There is history of intake of antibiotics and analgesics but had no relief.

On physical examination-tenderness was present in left flank region with lump felt in left iliac fossa around $5 \times 5 \mathrm{~cm}$. On per vaginal examination, cervical erosion noted with bilateral fornix tenderness with vague defined mass $4 \mathrm{~cm} \times 3 \mathrm{~cm}$ felt in left adnexal region. PAP Smear suggestive of inflammatory smear.

On Colonoscopy-patient was diagnosed to have sigmoid colon diverticulitis. Ultrasonography suggested of left adnexal complex cyst $4 \times 2.6 \mathrm{~cm}$ with septations and 
eccentric echogenic foci. Approximately $6 \times 5.6 \mathrm{~cm}$ adnexal cyst seen in pouch of douglas. Matted gut loops were seen.

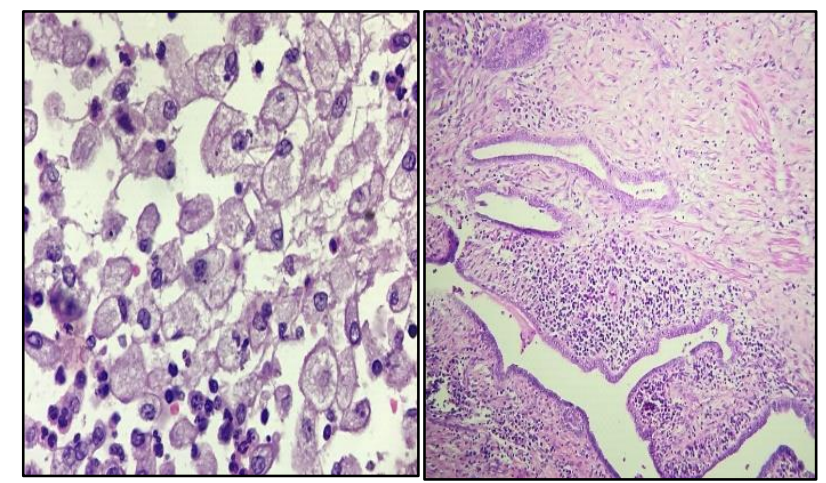

No evidence of malignancy seen in any of the sections examined.

Figure 1: Histology consistent with Xanthogranulomatous Salpingitis.

CT Scan whole abdomen revealed features of sigmoid diverticulitis with abscess formation. Her blood investigations showed raised CRP 89.4, CA 125-30, TLC-14000 and raised ESR-40mmHg. Clinical diagnosis of Sigmoid diverticulitis with left ovarian complex cyst was made.

Patient underwent Sigmoidecomy with Anterior Resection. Intraoperatively, mass involving sigmoid and uterus $8 \times 6 \mathrm{~cm}$ noted with left ovarian cyst so Total Abdominal Hysterectomy with Bilateral Salpingoophrectomy done and sample sent for histopathological examination. No complications noted. Patient recovered uneventfully postoperatively, was discharged on seventh day. Diagnosis of Xanthogranulomatous Salpingitis was made on basis of histopathological findings.

\section{Histopathological findings}

Multiple sections taken from mass attached to intestine, show fallopian tube having florid inflammatory granulation acute and chronic with foreign body giant cells reaction and foci of necrosis. Sheets of foamy macrophages noted. This inflammatory infiltrate is involving the serosa of adjacent colon.

\section{DISCUSSION}

Xanthogranulomatous Salpingitis is an inflammatory disease which has various etiological factors, but such factors and pathogenicity is yet not clear. Theories proposed are theory of infection, endometriosis, IUCD, inborn lipid metabolism of macrophage and drugs (antibiotics).

Amongst the theory proposed, theory of infection is most commonly accepted supported by clinical evidence of infection and growth of bacteria such as Escherichia coli, Bacteroides fragilis, Proteus vulgaris, all these organisms found in culture of affected tissue.

In female genital tract, 7 cases involved unilateral ovary, 5 cases involving unilateral fallopian tube, 1 case of bilateral fallopian tube, 2 cases of ovaries and fallopian tubes simultaneously.

Cases of endometriosis when diagnosed are termed as pseudoxanthogranulomatous salpingitis. In case of PID, xanthogranulomatous changes are termed to be pure xanthogranulomatous salpingitis Various histological and histochemical studies, reveal that histocytic component of pseudoxanthogranulomatous salpingitis have some differences with that of xanthogranulomatous salpingitis. ${ }^{16,17}$

The clinical presentation of xanthogranulomatous salpingitis includes pain abdomen, abdominal mass, anorexia. Gynaecological examination reveals adnexal mass with tenderness. Blood investigations shows increased CRP, TLC levels. Radiological findings may mimic malignant ovarian neoplasm and may lead to misdiagnosis. Differential diagnosis should be kept in mind considering all possible etiologies as they are interlinked and play important role as a contributory factor in the pathogenicity.

Our case of sigmoid diverticulitis and chronic PID possibly resulted in xanthogranulomatous salpingitis. The most likely explanation for its coexistence can be that chronic infection leads to tissue necrosis which releases cholesterol and other lipids from dead cells. Macrophages phagocytose these cell constituents leading to xanthomatous process. ${ }^{18}$

\section{CONCLUSION}

Though rare, xanthogranulomatous salpingitis should be kept in mind as one of the differential diagnosis while dealing with tubo ovarian masses. This can help in preventing misdiagnosis and radical surgeries if misdiagnosed as neoplasm. All possible efforts should be made to find causative factors and establish correct diagnosis.

\section{Funding: No funding sources \\ Conflict of interest: None declared \\ Ethical approval: Not required}

\section{REFERENCES}

1. Kunakemakorn P, Ontai H. Pelvic inflammatory pseudotumor: A case report. Am J Obstet Gynecol. 1976;26:286-7.

2. Shalev E, Zuckerman H, Rizescu I. Pelvic inflammatory pseudotumor (Xanthogranuloma) Acta Obstet Gynecol Scand. 1982;61:285-6. 
3. Pace EH, Voet RL, Melancon JT. Xanthogranulomatous oophoritis: an inflammatory pseudotumor of the ovary. International journal of gynecological pathology: official J Int Soc Gynecol Pathol. 1984;3(4):398-402.

4. Davis M, Whitley ME, Haque AK, Fenoglio-Preiser C, Waterman R. Xanthogranulomatous abscess of a Mullerian duct remnant. Dis Colon Rectum. 1986;29(11):755-9.

5. Ladetoged C, Loretzen M. Xanthogranulomatous inflammation of the female genital tract. Histopathol.1988;13:541-51.

6. Franco V, Florena AM, Guarneri G, Gargano G. Xanthogranulomatous salpingitis. Case report and review of the literature. Acta Euro Fertil. 1990;21(4):197-9.

7. Bates AW, Fegan AW, Baithun SL. Xanthogranulomatous cystitis associated with malignant neoplasms of the bladder. Histopathology. 1998;33:212-5.

8. Gray Y, Libbey NP. Xanthogranulomatous salpingitis and oophoritis:A case report and review of the literature. Arch Pathol Lab Med. 2001;125:260-3.

9. Furuya M, Murakami T, Sato O, Kikuchi K, Tanaka S, Shimizu M, Yoshiki T. Pseudoxanthomatous and xanthogranulomatous salpingitis of the fallopian tube: a report of four cases and a literature review. Int J Gynecol Pathol. 2002;21(1):56-9.

10. Idrees $\mathrm{M}$, Zakashansky $\mathrm{K}$, Kalir $\mathrm{T}$. Xanthogranulomatous salpingitis associated with fallopian tube mucosal endometriosis: a clue to the pathogenesis. Diag Pathol. 2007;11:117-21.

11. Shilpa D, Sulhyan K, Sachin B, Gosavi A, Ramteerthkar N. Xanthogranulomatous oophoritis: Case report. Indian J Basic Appl Med Res. 2013;2(7):745-9.

12. Zhang XS, Dong HY, Zhang LL, Desouki MM, Zhao C. Xanthogranulomatous inflammation of the female genital tract: Report of three cases. J Cancer. 2012;3:100-6.

13. Seidman JD, Oberer S, Bitterman P, Aisner SC. Pathogenesis of pseudoxanthomatous salpingiosis. Modern pathology: an official J United States Canadian Acad Pathol. 1993;6(1):53-5.

14. Gray Y, Libbey NP. Xanthogranulomatous salpingitis and oophoritis: a case report and review of the literature. Arch Pathol Laborat Med. 2001;125(2):260-3.

15. Punia RS, Aggarwal R, Mohan H. Xanthogranulomatous oophoritis and salpingitis: late sequelae of inadequately treated staphylococcal PID. Indian J Pathol Microbiol. 2003;46(1):80-1.

16. Furuya M, Murakami T, Sato O, Kikuchi K, Tanaka S, Shimizu M, et al. Pseudoxanthomatous and xanthogranulomatous salpingitis of the fallopian tube: a report of four cases and a literature review. Int J Gynecol Pathol. 2002;21(1):56-9.

17. Kostopoulou E, Daponte A, Kallitsaris A, Papamichali R, Kalodimos G, Messinis IE, et al. Xanthogranulomatous salpingitis: report of three cases and comparison with a case of pseudoxanthomatous salpingitis. Clin Exp Obstet Gynecol. 2008;35:291-4.

18. Yener N, Ilter E, Midi A. Xanthogranulomatous salpingitis as a rare pathologic aspect of chronic active pelvic inflammatory disease. Indian J Pathol Microbiol. 2011;54(1):141.

Cite this article as: Juneja SK, Virk SS, Sharma A, Sood N, Sood A. Xanthogranulomatous salpingitis pathological aspect of chronic pelvic inflammatory disease in a patient with sigmoid diverticulitis. Int $\mathbf{J}$ Reprod Contracept Obstet Gynecol 2018;7:3893-5. 